\title{
Seguridad y Migraciones.
}

Juan José Santander ${ }^{1}$

\section{Introducción}

Las migraciones, en tanto que desplazamiento ${ }^{2}$ de personas, constituyen por la condición humana de sus protagonistas, la materia prima de la historia, que es precisamente nuestro acontecer. Ellas afectarán el acontecer del nuevo siglo porque afectan todo: la demografía, la sociedad, la cultura, la política, la economía, la geografía, el comercio, etc., como en un juego de cascadas de dominó ${ }^{3}$.

Las sociedades más prósperas necesitan mano de obra, y trabajadores que aporten para sostener sus regímenes de seguridad y previsión social. Estas poblaciones emigradas modifican la composición de las sociedades que las reciben, y por ende también su cultura y sus modos de vida. Lo que queda por ver es qué fisonomía tendrán estas sociedades al promediar este centenio.

Los grados de desarrollo tan desparejos entre unos y otros países y a veces regiones, promueven además, ese éxodo de los más necesitados hacia los más países más prósperos que además, como dije, los necesitan. Tratar de controlar estos flujos se comprueba impracticable día a día, en la cantidad de residentes ilegales con que cuenta cualquiera de los países más económicamente poderosos, salvo, quizá, Japón. Organizarlos podría no ser tan irrealizable, en la medida que se ofrecieran mejores oportunidades concretas de progreso, empleo y perspectivas de mejorar la propia situación en los países emisores. De todas maneras, una organización "controlada" del ingreso de "extranjeros" no garantiza nada desde la perspectiva de la seguridad, en sentido estricto y en el sentido de seguridad humana ${ }^{4}$. La multiplicación de controles no es capaz de brindar la tranquilidad buscada, a lo sumo, podrá volver más difícil la realización de actos violentos, subrayando no obstante que no estamos tomando en consideración las oportunidades y posibilidades que la corrupción ofrece.

\footnotetext{
1 Juan José Santander es Ministro, en el Servicio Exterior de la Nación desde 1971. Profesor de Castellano y Ciencias Sociales UNL, posee una Maestría en Ciencias Sociales, Especialidad en Relaciones Internacionales (FLACSO, Ciudad Autónoma de Buenos Aires). Prestó servicios en las Embajadas Argentinas en Siria, Túnez, Libia, Venezuela, Singapur, Filipinas, Egipto, Marruecos e India entre 1973 y 2012 y fue condecorado por los Gobiernos de Alemania y Marruecos. Es Consultor y miembro del Comité de Estudios de África y Medio Oriente del CARI -Consejo Argentino para las Relaciones Internacionales- desde 1995.

2 Se usa el término en sentido no técnico y esto se aclara, tomando en cuenta que las "poblaciones desplazas" constituyen una tipología de la migración forzada. Puede consultarse sobre el tema a Castles (2003).

${ }^{3}$ Cabe recordar que la Organización Internacional para las Migraciones (2010), estima que 214 millones de personas viven fuera de su país de origen

${ }^{4}$ Puede consultarse al respecto, los artículos de Grasa y Morillas (Coords.) (2007).
} 


\section{Sociedades receptoras}

Un fenómeno acuciante e indiscutible es el envejecimiento de la población en los países desarrollados. Esto plantea problemas en dos vertientes: la de la disminución de la fuerza laboral y la de hacer frente, con los aportes de esa fuerza laboral mermada, al costo de la previsión y por otra parte, la mayor incidencia de las poblaciones relativamente nuevas que se asientan en cualquier país, respecto de las ya asentadas en su territorio durante previas generaciones. Ahora bien, en este caso hablamos de trabajadores, individualmente considerados. Falta sumarles los grupos familiares respectivos que, por un lado, se comprueba inciden en la natalidad del país receptor y, por otro, en la cantidad del flujo inmigratorio, ya que todas las legislaciones, sea a partir de la residencia o nacionalidad otorgada al trabajador inmigrado, sea a través de matrimonios mixtos -inmigrante con autóctono-, contemplan, con latitud variable, la figura del reagrupamiento familiar.

La carencia de población ha alcanzado ya una cuestión eminentemente vinculada a la seguridad: las fuerzas armadas. La apertura de las mismas a los latinoamericanos hijos de españoles por el gobierno de Madrid constituyó una muestra. Y un repaso por los nombres de varios responsables de los efectivos desplegados por EEUU en Iraq en su momento, brinda otra ${ }^{5}$.

La inmigración está aquí para quedarse. Es un dato del presente que moldeará fuertemente el futuro y debe ser tenida en cuenta en cualquier cálculo y diseño de planeamiento que desee ser exitoso, ya que, siguiendo las actuales proyecciones, su incidencia se irá acentuando con el andar del tiempo.

Resulta curioso constatar que en el momento en que la ciencia proclama que las diferencias mayores en el genoma humano aparecen entre individuos y no entre grupos étnicos, asistamos a un recrudecimiento de conflictos territoriales que se nutren en distingos raciales. Distingos que en el caso de los inmigrantes funcionan, según lo notable de sus diferencias con el fenotipo local, como inocultable señal de identificación. De todas maneras, estos dos últimos rasgos apuntados no hacen sino destacar la crucial importancia y la necesidad para la comunidad internacional y para cada uno de sus miembros, de un tratamiento serio y responsable de las cuestiones migratorias, con equidad y espíritu previsor, para preservar la paz -que es algo más que la ausencia de guerras- o restaurarla donde se ha perdido.

\footnotetext{
${ }^{5}$ Sería erróneo circunscribir el fenómeno a los otrora llamados países centrales. Una circunstancia parecida afecta, por ejemplo, a los países del Golfo Arábigo y Brunei, todos ellos petroleros y musulmanes y en el caso del Golfo, escasamente poblados, donde desde servicios incluidos el doméstico y los de seguridad, mano de obra no calificada y también técnicos y muchas otras actividades son asumidas por inmigrantes de variados orígenes pero donde predominan indios, paquistaníes, filipinos, cingaleses, egipcios y otros, no siempre musulmanes.
} 


\section{Sociedades emisoras}

Además de este aspecto, hay que abordar la situación de los países de origen: conflictos bélicos, desastres naturales, crisis económica, falta de perspectivas de progreso, sociedades tradicionales opresivas, discriminación o persecuciones étnicas, religiosas o políticas, y muchas otras más, impulsan desde personas o familias aisladas hasta contingentes masivos, a emigrar. Muchas veces valiéndose del medio de locomoción más primitivo: caminar; otras, de cualquiera que resulte accesible: embarcaciones precarias, polizones en tren de aterrizaje, camiones de transporte de mercancías y, aquí también, muchos otros más; tantos como motivos para huir o para buscar un futuro que desean y esperan sea mejor. Y que acaba a menudo con la muerte sin haber conseguido su propósito. Todo ello amplificado por los medios audiovisuales de comunicación, que difunden, en general, precisamente esas imágenes de vida próspera y no problemática en lo cotidiano. Donde lo no problemático implica asimismo hábitos más liberales y ocasiones de progreso que en las sociedades de origen se perciben como inaccesibles. Ello comporta, además, para el país emisor, la pérdida de la inversión realizada en el emigrado y se agrava al ser la pérdida mayor, en lo que se ha solido llamar "fuga de cerebros" ${ }^{6}$. En cualquier caso es una pérdida, más sensible cuanto de menos se dispone. Y son ciertamente los países que menos tienen quienes proporcionan más emigrantes. Es verdad que las remesas de dinero por parte de los trabajadores emigrados al país de origen constituyen una fuente de divisas importante, aunque se estima que en su mayoría no significan un estímulo real a las economías de los países emisores de migración, más allá de que puedan mejorar el bienestar de ciertos sectores de su población. A la vez, esta condición de extranjero, en la que algunos trabajadores inmigrantes se perciben a sí mismos, puede no colaborar con cualquier proceso de integración en la sociedad de acogida.

En cuanto a las circunstancias económicas en los países emisores, aparte de las excepcionales, desgraciadamente harto frecuentes, resultantes de guerras o desastres naturales, la marginalización creciente de los menos desarrollados en el comercio internacional y su dificultad de acceso a los mercados de mayor poder adquisitivo por prácticas proteccionistas en el ámbito de la agricultura y los textiles, ejemplos más notorios, significan otras tantas rémoras a su posibilidades efectivas de desarrollo económico genuino. Por lo demás, el influjo en las finanzas de capitales especulativos -muchas veces producto de ganancias en tráficos ilegales: drogas, armas, personas y otros-, distorsiona aún más esas posibilidades.

Crisis como las experimentadas en las últimas décadas, con alcance mundial, son prueba fehaciente de estos manejos y de sus consecuencias. La ayuda al desarrollo que proporcionan organismos internacionales y

\footnotetext{
6 La "fuga de cerebros » a menudo abarca en números mayores a técnicos de formación intermedia, que resultan más necesarios, según el grado de desarrollo técnico del país en cuestión, que los diplomados en disciplinas más sofisticadas.
} 
algunos países ricos, se diluye en tramas de corrupción que sostienen o involucran a los gobiernos de los países beneficiarios de la misma, por lo que el efecto creador de empleo que de ella se espera en función del crecimiento económico al que apunta esa ayuda, no se produce. De esos desempleados, jóvenes la mayor parte, se nutren los contingentes de candidatos a la emigración.

\section{Conclusiones}

El desnivel en el desarrollo y perspectivas sociales y económicas entre las distintas sociedades y los distintos países es una fuente permanente de conflictos.Ese mismo desnivel estimula la migración. El uso de la fuerza no garantiza la seguridad ni la intangibilidad en el propio territorio. Tampoco lo logra la multiplicación e intensificación de los controles, aunque puede disminuir ciertos riesgos.

La realidad de las migraciones obliga a considerar hacia el porvenir, las modalidades de integración de las poblaciones que se reciben, teniendo en cuenta en la medida en que resulten divergentes para cada grupo, las respectivas características culturales en el más amplio de los sentidos. Esto supone asumir cambios en la propia sociedad receptora, y ajustes por parte de los inmigrantes para lograr una integración lo más armoniosa posible. Es decir, considerar no solamente la seguridad en sentido estricto sino la seguridad humana, que tiende a una idea de seguridad que abarca a todos.

Sólo un consenso que estimule el conocimiento y la admisión de esas diferencias e impulse un desarrollo equitativo tanto entre sociedades como dentro de éstas, permitiría sentar las bases de una seguridad compartida y durable. 


\section{Referencias}

Castles, S. (2003). La política internacional de la migración forzada. Migración y Desarrollo, 1. http://www.redalyc.org/articulo.oa?id=66000106

Grasa, R. \& Morillas, P. (Coords.) (2007). Revista CIDOB d'afers internacionals, 76. Seguridad Humana: Conceptos, experiencias y propuestas. Barcelona: Fundació CIDOB-Editorial Bellaterra.

Organización Internacional para las Migraciones (2010). Informe sobre las migraciones en el mundo, 2010. El futuro de la migración: creación de capacidades para el cambio.

http://publications.iom.int/bookstore/index.php?main page=product info\&cPath=37\&products id=655\&la $\underline{\text { nguage }=e s}$ 